\title{
ANALISIS KEBUTUHAN LUAS LAHAN BASAH PERTANIAN PANGAN DALAM PEMENUHAN KEBUTUHAN PANGAN PENDUDUK KABUPATEN LAMPUNG BARAT
}

\author{
(Food Agriculture Wet Land Size Requirement Analysis in Fulfilling Food Requirement \\ of Population in West Lampung District)
}

\author{
Sumarlin ${ }^{1}$, Yayuk Farida Baliwati ${ }^{2}$, dan Ernan Rustiadi ${ }^{3}$
}

${ }^{1}$ Program Studi Manajemen Ketahahan Pangan (MKP), Sekolah Pascasarjana, IPB.
2 Departemen Gizi Masyarakat, Fakultas Ekologi Manusia (FEMA), IPB
Tel: 0251-8628304/8621258; Fax: 0251-8625846/8622276.
${ }^{3}$ Program Studi Ilmu Perencanaan Wilayah, Departemen Ilmu Tanah dan Sumberdaya Lahan,
Fakultas Pertanian (FAPERTA), IPB.

ABSTRACT

The general objective of this research was to analyze food agriculture wet land size requirement in fulfilling food requirement of population in West Lampung District. This research was conducted by using retrospective design and secondary data which then analyzed descriptively. The research used some data, it was : 1) demography data year 2001-2007 from Central Bureau of Statistics, 2) food balance sheet data year 2007 from Food Security Board of West Lampung District, 3) food consumption data year 2007 from Agriculture and Food Security Office of Lampung Province, 4) production data, productivity data, and plant index year 2002-2007 from Crops and Horticulture Office of West Lampung District, and 5) land potential of food agricultural development year 2004 from National Survey and Mapping Coordination Board. The result of the research indicates that rice requirement in West Lampung District until year 2012 can be fulfilled by production with wet land size utilized for rice planting in 2007 (13 320 hectar) and production 103711 ton dry harvest.

Keywords: food requirement, agricultural wet land size requirement

\section{PENDAHULUAN}

Produksi komoditas pangan utama Indonesia (padi, jagung, dan kedelai) tahun 19952000 cenderung menurun, sedangkan permintaan meningkat terutama sebagai akibat pertambahan jumlah penduduk. Sekitar $80 \%$ produksi padi dihasilkan dari lahan sawah beririgasi baik di Jawa (60\%) maupun luar Jawa (20\%). Selama tahun 1982-2000, terjadi perluasan areal tanam menyeluruh di Indonesia. $\mathrm{Di}$ Jawa perluasan areal tanam terutama disebabkan oleh meningkatnya intensitas tanam, sedangkan di luar Jawa tahun 1980-1990 karena perluasan areal baku sawah dan tahun 19902000 karena peningkatan intensitas tanam yang menandakan sulitnya dilakukan perluasan areal (Pasandaran et al., 2004).

Kabupaten Lampung Barat dengan laju pertumbuhan penduduk tahun 2002-2007 sebesar $1683 \%$ lebih tinggi dari pertumbuhan nasional yaitu $1.49 \%$ menyebabkan tekanan terhadap kemampuan memproduksi secara mandiri kebutuhan pangan penduduk Kabupaten Lampung Barat. Keterbatasan lahan budi daya pertanian yang hanya $23.22 \%$ (114 947.63 ha) dari luas wilayah yang dimiliki termasuk untuk pe- manfaatan pemukiman dan infrastruktur (BPS, 2008) merupakan faktor pembatas bagi Kabupaten Lampung Barat dalam meningkatkan ketersediaan pangan melalui produksi dalam daerah sebagai upaya terwujudnya kemandirian pangan.

Pertumbuhan intensitas tanam di Kabupaten Lampung Barat tahun 2002-2007 relatif meningkat sebesar $0.15 \%$ dengan peningkatan produktivitas lahan yang landai 0.03 ton/tahun (Dinas TPH, 2002-2007). Peningkatan produksi sebesar $64.02 \%$ pada tahun 2007 terhadap produksi tahun 2002 lebih diakibatkan adanya peningkatan luas areal tanam melalui peningkatan intensitas tanam dari 0.91 menjadi 1.64 . Apakah hal ini menandakan upaya perluasan areal di Kabupaten Lampung Barat telah mendekati ambang batas? Apakah Kabupaten Lampung Barat dapat meningkatkan kemampuan produksi beras guna mewujudkan kemandirian pangan dalam pemenuhan kebutuhan pangan penduduknya? Sementara itu, menurut Ariani et al. (2003) peningkatan produksi dan ketersediaan pangan dipengaruhi oleh luas lahan yang tersedia, produktivitas lahan, indeks pertanaman, harga pangan, dan harga sarana produksi. 
Untuk mengetahui seberapa besar kemampuan potensi produksi pangan pokok Kabupaten Lampung Barat dan luasan lahan sawah yang dibutuhkan agar mampu memproduksi pangan sesuai kebutuhan pangan dan gizi penduduknya, maka perlu dilakukan analisis terhadap kebutuhan luas lahan pertanian pangan Kabupaten Lampung Barat dalam pemenuhan kebutuhan pangan dan gizi penduduknya.

Penelitian ini bertujuan untuk: 1) Menganalisis kebutuhan produksi padi sawah penduduk Kabupaten Lampung Barat tahun 20082012; 2) Menganalisis kebutuhan luas lahan basah pertanian pangan dalam pemenuhan pangan penduduk Kabupaten Lampung Barat tahun 2008-2012; 3) Menganalisis pemenuhan kebutuhan luas lahan basah pertanian pangan dari potensi lahan pertanian yang ada di Kabupaten Lampung Barat.

\section{METODE PENELITIAN}

\section{Desain, Tempat, dan Waktu Penelitian}

Desain penelitian ini adalah retrospektif dengan analisis deskriptif. Penelitian dilakukan di Kabupaten Lampung Barat yang dipilih secara sengaja (purposive) dengan alasan yaitu: 1) Kabupaten Lampung Barat akan melakukan revisi tata ruang wilayah pada tahun 2009, 2) Kabupaten Lampung Barat merupakan kabukabupaten di Provinsi Lampung yang berbasis pertanian, perikanan dan kelautan dengan persentase luas kawasan budidaya pertanian sebesar 23.22\% dari luas wilayah. Penelitian ini dilaksanakan mulai bulan September 2008.

\section{Jenis dan Cara Pengumpulan Data}

Penelitian dilakukan dengan mengolah data dari berbagai instansi terkait yang seluruhnya merupakan data sekunder yaitu: yaitu 1) data kependudukan BPS tahun 2001-2007, 2) data ketersediaan pangan tahun 2007 yang berasal Neraca Bahan Makanan Kabupaten Lampung Barat, 3) data konsumsi pangan tahun 2007 sumber Dinas Pertanian dan Ketahanan Pangan Provinsi Lampung, 4) Data produksi, produktivitas dan indeks pertanaman tahun 2002-2007 sumber Dinas Tanaman Pangan dan Hortikultura Kabupaten Lampung Barat, dan 5) data potensi lahan pertanian pangan tahun 2004 sumber Bakosurtanal.

\section{Pengolahan dan Analisis Data}

Pengolahan data dilakukan dengan menggunakan program komputer Microsoft
Excell 2007, kemudian dianalisis secara deskriptif. Tahapan pelaksanaan pengolahan data sebagai berikut:

1. Menghitung kebutuhan pangan dan gizi penduduk

Untuk mengetahui kebutuhan pangan dan gizi penduduk Kabupaten Lampung Barat didasarkan pada komposisi penduduk menurut usia dan jenis kelamin sesuai dengan umur kecukupan gizi. Angka kecukupan energi regional ini digunakan dalam menentukan komposisi energi masing-masing kelompok pangan berdasarkan komposisi pangan nasional. AKE regional padi-padian disetarakan dengan beras kemudian dikonversi kedalam kebutuhan beras dengan satuan gram/kap/hr dan ton/tahun. Kemudian dijadikan dalam bentuk kebutuhan ketersediaan beras dengan mengalikan kebutuhan beras ton/tahun dikali $110 \%$.

2. Menghitung kebutuhan produksi padi (ton GKP/th)

Perhitungan kebutuhan produksi padi sawah didasarkan pada kebutuhan ketersediaan yang telah ditambahkan kebutuhan penggunaan lain (pakan, bibit, dan tercecer) serta adanya faktor konversi perubahan bentuk dari gabah kering panen (GKP), gabah kering giling (GKG) menjadi beras dengan menggunakan rumus:

$$
\begin{aligned}
& \text { On }{ }_{(i, a)}=\left(F d n_{(i, a)} \times(100+\% f+\% s+\% w)\right) / \% R \\
& \text { On }=\text { Kebutuhan produksi pangan (ton } \\
& \text { GKP/tahun) }
\end{aligned}
$$

3. Menghitung kebutuhan luas lahan sawah.

Perhitungan kebutuhan luas lahan sawah dilakukan dengan menggunakan rumus sebagai berikut:

$$
\operatorname{Ln}(i, a)=\left[O n_{(i, a)} /(I \times Y)\right] \times(100+G p) \%
$$

Ln = Kebutuhan luas lahan pertanian pangan (ha)

$\mathrm{I}=$ = Indeks Pertanaman (\%)

$\mathrm{Y}=$ Produktivitas lahan komoditas pangan per musim tanam (ton/ha/musim) 
$\mathrm{Gp}=$ Rata-rata persentase gagal panen tahun 2002-2007 (\%)

Hasil perhitungan ini sebagai dasar perhitungan rasio pemenuhan kebutuhan luas lahan sawah dari potensi lahan padi sawah yang sesuai dan tersedia di Kabupaten Lampung Barat dengan menggunakan rumus :

$\mathrm{RL}_{(\mathrm{i}, \mathrm{a})}=(\mathrm{LPt} / \mathrm{Ln}) \times 100 \%$

$\mathrm{RL}=$ Rasio potensi lahan terhadap kebutuhan luas lahan (\%)

$\mathrm{LPt}=$ Potensi lahan pertanian pangan di Kabupaten Lampung Barat (ha)

4. Menghitung kebutuhan luas lahan sawah tahun 2012

Perhitungan kebutuhan luas lahan sawah tahun 2012 dengan asumsi laju pertumbuhan penduduk Kabupaten Lampung Barat adalah tetap (1.683\% per tahun) dengan menggunakan 4 skenario yaitu:

a. Skenario I, dengan asumsi konsumsi per kapita penduduk ideal, produktivitas dan indeks pertanaman (IP) naik.

b. Skenario II, dengan asumsi konsumsi per kapita penduduk tetap, produktivitas dan indeks pertanaman (IP) naik.

c. Skenario III, dengan asumsi konsumsi per kapita penduduk ideal, produktivitas dan indeks pertanaman (IP) tetap.

d. Skenario IV, dengan asumsi konsumsi per kapita penduduk, produktivitas dan indeks pertanaman adalah tetap.

\section{Asumsi Penelitian}

Penelitian ini menggunakan asumsiasumsi sebagai berikut:

1. Bahwa kebutuhan beras penduduk Lampung Barat keseluruhan dipenuhi dari produksi dalam daerah (swasembada absolut).

2. Bahwa produktivitas lahan merupakan gambaran yang mewakili akumulasi penerapan teknologi, input usaha tani dan sumber daya manusia yang digunakan dalam usaha tani. Produktivitas lahan padi sawah dikatakan naik jika kenaikannya mencapai angka tertinggi produktivitas gabah kering panen dalam kurun waktu 2002-2007 yaitu 4.50 ton/ha/musim (sumber: Dinas Tanaman Pangan dan Hortikultura tahun 2003-2008, secara lengkap terlihat pada Tabel 1).

3. Bahwa indeks pertanaman padi sawah dikatakan naik jika luas lahan dengan indeks pertanaman 2 bertambah sebesar 3\%/tahun dari luas tahun 2007. Hal ini didasarkan pada peningkatan indeks pertanaman padi sawah yang mungkin dapat dicapai pada tahun 2012 adalah sebesar rata-rata pertumbuhan indeks pertanaman Kabupaten Lampung Barat tahun 2002-2007 yaitu 15\% dari luas lahan tahun 2007 (sumber: Dinas Tanaman Pangan dan Hortikultura tahun 2003-2008, secara lengkap terlihat pada Tabel 1).

4. Bahwa konsumsi ideal merupakan konsumsi pangan yang memenuhi angka kecukupan energi regional kelompok pangan padipadian berdasarkan persentase komposisi energi yang berlaku secara nasional. Konsumsi aktual merupakan konsumsi pangan yang berdasarkan hasil survei konsumsi pangan tahun 2007 Dinas Pertanian dan Ketahanan Pangan Provinsi Lampung.

5. Bahwa laju pertumbuhan penduduk dikatakan tetap jika mengikuti laju pertumbuhan penduduk rata-rata tahun 2001-2007 sesebesar 1.683\% pertahun (sumber: BPS, Lampung Barat dalam Angka 2006-2007).

6. Bahwa tingkat gagal panen padi sawah mengikuti rata-rata persentase gagal panen tahun 2002-2007 sebesar $3.45 \%$ dari luas tanam yang ada (sumber: Dinas Tanaman Pangan dan Hortikultura tahun 2003-2008, secara lengkap terlihat pada Tabel 1).

\section{Keterbatasan Penelitian}

1. Kebutuhan luas lahan basah pertanian pangan dihitung berdasarkan kebutuhan ideal maupun aktual produksi padi sawah GKP penduduk Kabupaten Lampung Barat.

2. Kebutuhan produksi padi dihitung tanpa memperhatikan kebutuhan untuk penggunaan industri, impor, ekspor dan adanya perubahan stok.

\section{HASIL DAN PEMBAHASAN}

\section{Kondisi Umum}

Luas wilayah Kabupaten Lampung Barat sebesar $4950.40 \mathrm{~km}^{2}$ atau $13.99 \%$ dari luas wilayah Provinsi Lampung dengan mata pencaharian pokok sebagian besar penduduknya sebagai petani. Wilayah Kabupaten Lampung Barat secara administratif meliputi 17 (tujuh belas) kecamatan dan terdiri dari 195 pekon (desa) serta 6 kelurahan dengan jumlah penduduk 410723 jiwa dan laju pertumbuhan sebesar $1.683 \%$ /tahun (BPS, 2008). Potensi lahan padi 
sawah Kabupaten Lampung Barat berdasarkan kesesuaian lahan yang dimiliki, menurut Bakosurtanal (2004) terdapat 21791.2 hektar. Kondisi lahan padi sawah di Kabupaten Lampung Barat tahun 2008 menurut Dinas PU (2008) terdiri dari 4032 hektar beririgasi teknis, 14562.93 hektar beririgasi perdesaan, dan 3197.27 merupakan lahan sawah tadah hujan.

Lahan padi sawah di Kabupaten Lampung Barat memperlihatkan bahwa tahun 2007 terjadi penurunan luas lahan seluas 1115 hektar dari tahun 2002 yang disertai dengan adanya peningkatan indeks pertanaman padi sawah dari 0.91 menjadi 1.64 mampu meningkatkan produksi padi sawah sebesar $62.04 \%$ dari 90.088 ton Gabah Kering Panen (GKP) menjadi 145977 ton GKP dengan produktivitas lahan yang cenderung stabil (4.35 ton/ha) (Tabel 1).

\section{Kebutuhan Pangan dan Gizi Penduduk Lampung Barat}

Angka Kecukupan Energi (AKE) regional Kabupaten Lampung Barat adalah 2071 kkal/ kapita/hari dengan angka ketersediaan energi sebesar 2278 kkal/kapita/hari. Komposisi pangan ideal penduduk Kabupaten Lampung Barat berdasarkan komposisi pangan standar nasional dapat dilihat pada Tabel 2 .

Dari Tabel 2 tersebut terlihat bahwa produksi pangan secara akumulasi menunjukkan kinerja yang sangat baik mencapai $134 \%$ dari ideal. Namun demikian, berdasarkan pemenuhan kebutuhan ketersediaan pada setiap kelompok pangan masih terdapat kinerja produksi yang masih kurang (dibawah 90\% kebutuhan ketersediaan) yaitu pada: umbi-umbian $89 \%$, pangan hewani $31 \%$, buah/biji berminyak $0 \%$, kacang-kacangan 15\%, gula 74\% dan lainlain $0 \%$. Hal ini berakibat pada tingkat konsumsi energi penduduk yang masih kurang yaitu hanya $94 \%$ dari tingkat konsumsi ideal (1947 kkal/kap/hr).

Selain itu, adanya ketergantungan terhadap kelompok pangan padi-padian yang sangat tinggi mencapai $62.56 \%$ dari total konsumsi energi penduduk tahun 2007. Berdasarkan hasil survei konsumsi pangan tahun 2007 oleh Dinas Pertanian dan Ketahanan Pangan

Tabel 1. Pertumbuhan Produksi, Luas Panen, Luas Lahan, Gagal Panen, Produktivitas, dan Indeks Pertanaman Padi Sawah Kabupaten Lampung Barat Tahun 2002-2007

\begin{tabular}{|c|c|c|c|c|c|c|c|c|}
\hline No & Uraian & 2002 & 2003 & 2004 & 2005 & 2006 & 2007 & $\begin{array}{c}\text { Rata-rata } \\
\text { Pertumbuhan }\end{array}$ \\
\hline 1. & Produksi (ton GKP) & 90.088 & 96.075 & 102.682 & 104.883 & 113.184 & 145.977 & 11.177 .8 \\
\hline 2. & Luas panen (ha) & 20.154 & 21.350 & 23.605 & 24.111 & 26.019 & 33.328 & 2.634 .80 \\
\hline 3. & Luas lahan (ha) & 22.174 & 16.019 & 16.291 & 27.322 & 20.542 & 20.289 & 2.260 .60 \\
\hline 4. & Gagal Panen (\%) & 4.78 & 8.57 & 1.24 & 10.81 & -20.50 & 15.8 & 3.45 \\
\hline 5. & $\begin{array}{l}\text { Produktivitas } \\
\text { (ton/ha/musim) }\end{array}$ & 4.47 & 4.50 & 4.35 & 4.35 & 4.35 & 4.38 & 0.03 \\
\hline 6. & Indeks Pertanaman (\%) & 0.91 & 1.33 & 1.45 & 0.88 & 1.27 & 1.64 & 0.15 \\
\hline
\end{tabular}

Sumber : Dinas Tanaman Pangan dan Hortikultura 2003-2008

Tabel 2. Ketersediaan Energi dan Konsumsi Energi Regional Ideal dan Aktual menurut Kelompok Pangan Kabupaten Lampung Barat Tahun 2007

\begin{tabular}{|c|c|c|c|c|c|c|c|}
\hline \multirow{2}{*}{ No } & \multirow{2}{*}{ Kelompok Pangan } & \multicolumn{3}{|c|}{ Konsumsi Energi (kkal/kap/hr) } & \multicolumn{3}{|c|}{ Ketersediaan Energi (kkal/kap/hr) } \\
\hline & & ideal *) & Aktual**) & Selisih (\%) & ideal*) & Aktual***) & Selisih (\%) \\
\hline 1 & Padi-padian & 1036 & 1218 & 118 & 1139 & 2175 & 191 \\
\hline 2 & Umbi-umbian & 124 & 57 & 46 & 137 & 122 & 89 \\
\hline 3 & Pangan hewani & 249 & 162 & 65 & 273 & 85 & 31 \\
\hline 4 & Minyak dan Lemak & 207 & 211 & 102 & 228 & 437 & 192 \\
\hline 5 & Buah/Biji berminyak & 62 & 14 & 23 & 68 & 0 & 0 \\
\hline 6 & Kacang-kacangan & 104 & 111 & 107 & 114 & 17 & 15 \\
\hline 7 & Gula & 104 & 94 & 90 & 114 & 85 & 74 \\
\hline 8 & Sayur dan Buah & 124 & 77 & 62 & 137 & 137 & 100 \\
\hline \multirow[t]{2}{*}{9} & Lain-lain & 62 & 3 & 5 & 68 & 0 & 0 \\
\hline & Total & 2071 & 1947 & 94 & 2278 & 3059 & 134 \\
\hline
\end{tabular}

Keterangan :

*) = berdasarkan AKE Regional Lampung Barat 2007

**) = berdasarkan survei konsumsi pangan Lampung Barat 2007; sumber Dinas Pertanian dan Ketahanan Pangan Provinsi Lampung

***) = berdasarkan Neraca Bahan Makanan Lampung Barat 2007; sumber Badan Ketahanan Pangan Kabupaten Lampung Barat 
Propinsi Lampung, kontribusi konsumsi energi tertinggi pada kelompok pangan padi-padian penduduk Kabupaten Lampung Barat didominasi beras mencapai $96.12 \%$ dari $1218 \mathrm{kkal} /$ $\mathrm{kap} / \mathrm{hr}$.

\section{Kebutuhan Pangan Pokok Beras}

Berdasarkan angka kebutuhan ideal energi dan konsumsi aktual aktual yang berasal dari pangan pokok beras penduduk Kabupaten Lampung Barat dengan kandungan energi 360 kkal dan berat dapat dikonsumsi $100 \%$ setiap 100 gram beras, maka kebutuhan konsumsi ideal adalah 43141.89 ton/tahun dan kebutuhan konsumsi aktual adalah 50720.87 ton/tahun. Hal ini bila dikonversi kedalam bentuk ketersediaan beras ideal yaitu 47456.08 ton/ tahun dan ketersediaan beras aktual yaitu 55792.96 ton/tahun sehingga mengalami selisih $117.57 \%$ lebih tinggi kebutuhan ketersediaan sebagai akibat pola konsumsi beras yang berlebihan penduduk Kabupaten Lampung Barat.

Tingginya kebutuhan konsumsi pangan ini akan berdampak pada tingginya kebutuhan sarana prasarana, infrastruktur, luas lahan, input usaha tani dan modal yang harus disediakan untuk memenuhi kebutuhan ketersediaan beras penduduk.

\section{Kebutuhan Produksi Pangan Pokok}

Kebutuhan produksi ideal padi gabah kering panen (GKP) Kabupaten Lampung Barat tahun 2007 sebesar 95415.22 ton gabah kering panen dan kebutuhan produksi aktual sebesar 112177.35 ton gabah kering panen. Kebutuhan produksi gabah kering panen tersebut masih berada di bawah ketersediaan aktual berdasarkan neraca bahan makanan (NBM) Kabupaten Lampung Barat 2007 yaitu 150409 ton GKP. Kebutuhan produksi ini belum memasukkan kebutuhan industri, impor, ekspor dan adanya perubahan stok serta kebutuhan pada hari-hari besar nasional.

Ketersediaan padi gabah kering panen Kabupaten Lampung Barat tahun 2007 dipenuhi dari kontribusi padi sawah sebesar $97.06 \%$ atau 145977 ton dan padi ladang 2.94\% atau 4.432 ton (BPS, 2008). Hal ini menunjukkan kebutuhan pangan pokok beras dapat dipenuhi secara mandiri dari produksi padi sawah sebagai bentuk kemandirian pangan. Tingginya kontribusi padi sawah terhadap pemenuhan kebutuhan beras Kabupaten Lampung Barat, maka lahan sawah perlu mendapat perlindungan agar tidak terjadi konversi menjadi lahan non-sawah yang dapat mengakibatkan ketidakmampuan dalam memenuhi kebutuhan pangan beras penduduk dan mengancam ketahanan pangan Kabupaten Lampung Barat.

\section{Kebutuhan Luas Lahan Pertanian Pangan}

Kebutuhan luas lahan padi sawah dalam pemenuhan kebutuhan pangan ideal penduduk Kabupaten Lampung Barat tahun 2007 adalah 13741.38 hektar. Kebutuhan luas lahan padi sawah menjadi lebih tinggi dengan adanya pola konsumsi yang terjadi di masyarakat Kabupaten Lampung Barat tahun 2007 (survei konsumsi 2007) yaitu 16155.40 ha. Menurut Rustiadi \& Wafda (2008) penyediaan lahan pertanian berkaitan dengan kapasitas produksi pangan ditentukan oleh luas lahan produksi, produktivitas lahan, tingkat kebutuhan konsumsi pangan (ketergantungan pada beras), laju luasan konversi dan jumlah penduduk. Sehingga semakin tinggi ketergantungan konsumsi masyarakat terhadap beras maka semakin tinggi pula kebutuhan lahan pertanian.

Potensi lahan padi sawah di Kabupaten Lampung Barat menurut Bakosurtanal (2004) adalah 21791.20 hektar, maka rasio pemenuhan kebutuhan luas lahan padi sawah tahun 2007 adalah $158.58 \%$ pada kebutuhan luas lahan ideal dan $134.89 \%$ pada kebutuhan luas lahan aktual. Kondisi ini termasuk dalam kategori memenuhi atau potensi lahan $\geq 100 \%$ dari kebutuhan lahan. Sehingga kebutuhan lahan untuk memproduksi beras dalam pemenuhan kebutuhan penduduk masih menjadi peluang dalam membangun ketahanan pangan melalui kemandirian pangan beras. Potensi lahan yang luas ini merupakan cadangan lahan pangan bagi pemenuhan kebutuhan pangan penduduk Kabupaten Lampung Barat yang harus terjaga tidak terkonversi dan terdegradasi kesuburannya.

Kebutuhan Luas Lahan Pertanian Pangan Tahun 2012

Kebutuhan luas lahan padi sawah Kabupaten Lampung Barat pada tahun 2012 dengan asumsi konsumsi beras perkapita ideal (105.04 $\mathrm{kg} / \mathrm{kap} / \mathrm{th}$ ) dan laju pertumbuhan penduduk tetap (1.683\%), serta naiknya produktivitas menjadi 4.5 ton GKP perhektar dan indeks pertanaman padi sawah menjadi $1.79 \%$ (skenario I), maka dibutuhkan luas lahan sawah 13320 hektar.

Hal ini berarti hingga tahun 2012 guna memenuhi kebutuhan pangan beras ideal masih dapat dipenuhi dari luas lahan produksi yang ada, dengan asumsi tidak terjadi konversi lahan sawah menjadi non sawah baik pertanian maupun non pertanian (Tabel 3). Kondisi ini 
menurut Rustiadi \& Wafda (2008) memerlukan perhatian pemerintah untuk menghalangi terjadinya konversi lahan, peningkatan infrastruktur pertanian terutama jaringan irigasi dan meningkatkan produktivitas lahan.

Kondisi ini juga menggambarkan landman rasio yang harus dipenuhi guna memenuhi kebutuhan pangan beras penduduk Kabupaten Lampung Barat adalah 34 orang perhektar lahan sawah. Sehingga perlu adanya perhatian Pemerintah Kabupaten Lampung Barat untuk melindungi seluruh potensi lahan sawah yang dimiliki dengan mengupayakan tidak terjadinya konversi lahan padi sawah dan peningkatan degradasi kesuburan lahan sawah dengan menjadikan seluruh potensi lahan sawah merupakan lahan maupun kawasan pertanian pangan berkelanjutan di Kabupaten Lampung Barat dalam Rencana Tata Ruang Wilayah (RTRW) yang akan disusun tahun 2009. Selain itu perlu adanya peningkatan infrastruktur irigasi, sarana prasarana pertanian pangan, serta pendampingan oleh aparatur terkait (penyuluh, fasilitator daerah, mitra tani dan sebagainya).

Kebutuhan luas lahan padi sawah akan semakin tinggi jika pola konsumsi penduduk tidak mengalami perbaikan ke arah pola konsumsi gizi cukup dan seimbang serta tidak terjadinya peningkatan produktivitas lahan dan indeks pertanaman yaitu seluas 17560 ha (skenario IV). Sehingga untuk mewujudkan kemandirian pangan, Pemerintah Kabupaten Lampung Barat harus mengupayakan terwujudnya skenario I yaitu terjadinya perbaikan pola konsumsi pangan dan gizi cukup dan seimbang serta mengupayakan peningkatan produktivitas dan indeks pertanaman padi sawah. Hal ini di- harapkan akan mampu mengurangi tingkat ketergantungan konsumsi penduduk terhadap beras dan berkembangnya industri pangan olahan subtitusi beras dari kelompok pangan umbiumbian.

Pemenuhan kebutuhan pangan penduduk Kabupaten Lampung Barat tahun 2012 akan berbeda apabila tidak dilakukan perubahan kebijakan ke arah terjadinya diversifikasi konsumsi pangan pokok dan peningkatan produksi melalui intensifikasi serta diversifikasi pangan. Pola penanaman pada lahan sawah oleh penduduk Kabupaten Lampung Barat dalam upaya diversifikasi pangan telah dilakukan. Kebiasaan petani di kecamatan-kecamatan pesisir (Lemong, Pesisir Utara, Karya Penggawa, Pesisir Tengah, Pesisir Selatan, Bengkunat, Bengkunat Belimbing, dan Ngambur) melakukan pola tanam dengan menanam tanaman jagung,kacang tanah, kacang panjang, dan kedelai pada saat pergantian musim tanam. Sedangkan petani di kecamatan Sumber Jaya, Sekincau, Way Tenong, Suoh, Gedung Surian, Belalau, Batu Brak, Balik Bukit dan Sukau melakukannya dengan tanaman jagung. Sehingga pada lahan sawah tersebut tidak semata menghasilkan padi saja (N. Lingga K. 23 Pebruari 2009; komunikasi pribadi).

\section{KESIMPULAN}

Kebutuhan produksi padi untuk pemenuhan kebutuhan konsumsi ideal penduduk Kabupaten Lampung Barat pada tahun 2012 mencapai 103711 ton GKP dengan jumlah penduduk 446468 jiwa.

Tabel 3. Kebutuhan luas lahan sawah Kabupaten Lampung Barat tahun 2012

\begin{tabular}{llrrrrr}
\hline \multirow{2}{*}{ No } & \multicolumn{1}{c}{ Variabel/Parameter } & Kondisi & \multicolumn{4}{c}{ Skenario } \\
\cline { 5 - 7 } & & Tahun 2007 & \multicolumn{1}{c}{ I } & \multicolumn{1}{c}{ II } & \multicolumn{1}{c}{ III } & IV \\
\hline 1 & Jumlah Penduduk (jiwa) & $410723^{\text {a) }}$ & 446468 & 446468 & 446468 & 446468 \\
2 & Konsumsi (kg/kap/ thn) & $123.49^{\text {b) }}$ & 105.04 & 123.49 & 105.04 & 123.49 \\
3 & Konsumsi Total (ton/tahun) & 50721 & 46897 & 55134 & 46897 & 55134 \\
4 & Produksi (ton GKP) & $145977^{\text {c) }}$ & 103711 & 121927 & 103711 & 121927 \\
5 & Produktivitas lahan (ton GKP/ha) & $4.38^{\text {c) }}$ & 4.50 & 4.50 & 4.38 & 4.38 \\
6 & Indeks Pertanaman (\%) & $1.64^{\text {c) }}$ & 1.79 & 1.79 & 1.64 & 1.64 \\
7 & Luas lahan sawah (hektar) & $20289^{\text {c) }}$ & 13320 & 15659 & 14936 & 17560 \\
8 & Luas panen sawah (hektar) & $33328^{\text {c) }}$ & 23047 & 27095 & 23678 & 27837 \\
\hline 9 & Potensi lahan (ha) & $21791.2^{\text {d) }}$ & 21791.2 & 21791.2 & 21791.2 & 21791.2 \\
\hline 10 & Selisih (ha) $=(9)-(7)$ & 1502.20 & 8471.67 & 6132.13 & 7353.23 & 4817.24 \\
\hline
\end{tabular}

Keterangan:

a) : BPS, Lampung Barat Dalam Angka 2008

b) : Survei Konsumsi Pangan Lampung Barat 2007; sumber Dinas Pertanian dan Ketahanan Pangan Provinsi Lampung 2007

c) : Dinas Tanaman Pangan dan Hortikultura 2008

d) : Bakosurtanal, Data Tematik Lampung Barat 2004 
Kebutuhan luas lahan padi sawah Kabupaten Lampung Barat tahun 2012 guna memenuhi kebutuhan pangan ideal yaitu 13320 hektar.

Pada tahun 2012 pemenuhan kebutuhan produksi padi sawah Kabupaten Lampung Barat masih dapat terpenuhi dari produksi dengan luas lahan padi sawah yang telah dimanfaatkan tahun 2007.

\section{DAFTAR PUSTAKA}

Ariani M, Malian AH, \& Mardianto S. 2003. Faktor-faktor yang mempengaruhi Produksi, konsumsi, dan harga beras serta inflasi bahan makanan. Pusat Penelitian dan Pengembangan Sosial Ekonomi Pertanian, Bogor.

[Bakosurtanal] Badan Koordinasi Survey dan Pemetaan Nasional. 2004. Laporan Akhir Penyusunan Data Tematik Lampung Barat dan Sistem Informasinya. Kerjasama Bappeda Lampung Barat, Bakosurtanal dan Pusat Survei Sumberdaya Alam Darat, Lampung Barat

[BPS] Badan Pusat Statistik. 2008. Lampung Barat Dalam Angka Tahun 2007. Kerja- sama BPS dan Bappeda Lampung Barat, Liwa.

[Dinas PU] Dinas Pekerjaan Umum. 2008. Laporan Akuntabilitas Kinerja Instansi Pemerintah Tahun 2007, Lampung Barat.

[Dinas TPH] Dinas Tanaman Pangan dan Hortikultura. 2003-2008. Laporan Bulanan Keragaan Panen dan Produksi Padi dan Palawija Kabupaten Lampung Barat Tahun 2002-2007, Lampung Barat.

Pasandaran E, Irianto G, \& Zuliasri N. 2004. Pendayagunaan dan Peluang Pengembangan Irigasi bagi Peningkatan Produksi Padi. Dalam: F Kasryno, E Pasandaran, Fagi AM. (Eds.), Ekonomi Padi dan Beras. Badan Penelitian dan Pengembangan Pertanian. Departemen Pertanian, Jakarta. hlm 277-293.

Rustiadi E \& Wafda R. 2008. Urgensi Pengembangan Lahan Pertanian Pangan Abadi dalam Perspektif Ketahanan Pangan. Dalam: Arsyad S \& Rustiadi E. (Eds.), Penyelamatan Tanah, Air, dan Lingkungan. Yayasan Obor Indonesia, Jakarta. hlm $61-90$. 